\title{
Immunohistochemical expression of epithelial and stromal immunomodulatory signalling molecules is a prognostic indicator in breast cancer
}

\author{
Elin Richardsen ${ }^{1,2^{*}+}$, Rebecca Dale Uglehus ${ }^{1+}$, Stein Harald Johnsen ${ }^{3,4}$ and Lill-Tove Busund ${ }^{2,1+}$
}

\begin{abstract}
Background: The immune system has paradoxical roles during cancer development and the prognostic significance of immune modulating factors is controversial. The aim of this study was to determine the expression of cyclooxygenase 2 (COX-2), transforming growth factor-beta (TGF- beta), interleukin-10 (IL-10) and their prognostic significance in breast cancers. Ki67 was included as a measure of growth fraction of tumor cells.

Methods: On immunohistochemical stained slides from 38 breast cancer patients, we performed digital video analysis of tumor cell areas and adjacent tumor stromal areas from the primary tumors and their corresponding lymph node metastases. COX-2 was recorded as graded staining intensity.

Results: The expression of TGF-beta, IL-10 and Ki67 were recorded in tumor cell areas and adjacent tumor stromal areas. In both primary tumors and metastases, the expression of COX-2 was higher in the tumor stromal areas than in the tumor cell areas (both $P<0.001$ ). High stromal staining intensity in the primary tumors was associated with a 3.9 (95\% Cl 1.1-14.2) times higher risk of death compared to the low staining group $(P=0.036)$. The expression of TGF-beta was highest in the tumor cell areas of both primary tumors and metastases (both $P<0.001$ ). High stromal expression of TGF-beta was associated with increased mortality. For IL-10, the stromal expression was highest in the primary tumors $(P<0.001)$, whereas in the metastases the expression was highest in tumor cell areas $(P<0.001)$. High IL-10 expression in tumor- and stromal cell areas of primary tumors predicted mortality. Ki67 was higher expressed in tumor stromal areas of the metastases, and in tumor cell areas of the primary tumors $(P<$ 0.001). Ki67 expression in tumor cell areas and stromal areas of the metastases was independently associated with breast cancer mortality.
\end{abstract}

Conclusions: Stromal expression of COX-2, TGF-beta and Ki67 may facilitate tumor progression in breast cancer.

\section{Background}

Epithelial-stromal interactions are important for tumor development and progression [1]. The stroma surrounding solid tumors contains activated and recruited cells like fibroblasts, innate and adaptive immune cells, and endothelial cells which can be supportive and responsive agents in tumorigenesis [1,2]. An abnormal stroma may cause dysfunction of epithelial-mesenchymal interactions

\footnotetext{
* Correspondence: elin.richardsen@unn.no

† Contributed equally

1 Department of Clinical Pathology, University Hospital of Northern Norway, N-9038 Tromsø, Norway

Full list of author information is available at the end of the article
}

which promotes progression of preneoplastic lesions to malignancy [3]. Changes in the stroma environment may lead to selection of cells with altered survival characteristics. In normal mammary tissue stroma plays a major role in control and regulation of physiological processes in the breast [4]. The complexity of stromal reaction and the signalling mechanisms between tumor and stromal cells in breast cancer is incompletely understood, not least because stroma is continuously remodelled during tumor progression $[5,6]$.

The cytokine cyclooxygenase-2 (COX-2) is frequently expressed by cancerous cells. It is Not constitutively

\section{Biomed Central}


expressed, but can be rapidly induced by oncogenes, other cytokines, chemokines, growth factors, hypoxia, ultraviolet light, and epidermal growth factors. The transcription factors, nuclear factor- $\kappa \mathrm{B}$ (NF- $\kappa \mathrm{B})$, hypoxia-inducible factor $1 \alpha$ (HIF1 $\alpha$ ), and activator of transcription 3 (STAT3) coordinate the production of COX-2 and prostaglandins [7-11]. In early tumor outgrowth elevated transforming growth factor- $\beta$ (TGF- $\beta$ ) is tumor suppressive, whereas at later stages it may act as a promoter of tumor progression $[12,13]$. TGF- $\beta$ induces $\alpha$-smooth muscle actin and collagen production in culture fibroblasts [14] and is a potential mediator of desmoplastic responses in tumors. Desmoplasia in invasive tumors and metastases is morphologically characterized by extensive proliferation of fibroblast-like cells and extracellular matrix (ECM); inflammation and immune responses represented by lymphocytes, macrophages, dendritic cells; and tumor angiogenesis [15]. Loss of TGF- $\beta$ sensitivity in carcinoma cells is frequently accompanied by increased expression of TGF- $\beta$ in the same cells [16]. TGF- $\beta$ is elevated in cancer cells compared to normal epithelial cells, and appears to be even more elevated in poorly differentiated tumors $[17,18]$.

The significance of interleukin 10 (IL-10) within the tumor microenvironment is debated because it is dependent of the malignant cells, tumor-infiltrating macrophages and lymphocytes $[19,20]$. IL-10 derived from regulatory T-cells in the tumor or from cells in the tumor microenvironment may stimulate tumor progression $[21,22]$. In tumor tissue, IL-10 has both immunosuppressive properties (potentially cancer promoting due to inhibitory effects on antigen presenting capacity) and anti-angiogenic properties (potentially cancer inhibiting) [23-25].

Ki67 is a nuclear protein, which is expressed during all the active phases of cell cycle (G1, S, G2 and mitoses), but is absent from the resting phase (G0). Ki67 is strictly associated with cell proliferation during the cell cycle interphase. The Ki67 antigen can be exclusively detected within the cell nucleus, whereas in mitosis most of the protein is relocated to the surface of chromosomes. Studies have shown that Ki67 is associated with tumor aggressiveness in breast cancer [26].

Previous studies have highlighted the epithelial-stromal interactions and emphasized the stromal-epithelial interface as critical mediators of tumor progression [27-31]. In this study, we evaluated the prognostic significance of the immunomodulatory signalling molecules COX-2, TGF- $\beta$, IL-10 and Ki67 in tumor epithelium and stromal areas of human breast cancer.

\section{Methods}

Patients

Primary tumor tissues and tissues from the corresponding lymph node metastases were investigated in 38 untreated breast cancer patients. The specimens were diagnosed at the University Hospital of Northern Norway (UNN) from 2000 to 2003. The initial diagnoses were based on fine-needles biopsies, lumpectomy specimens and resection specimens. To be included, patients must have a confirmed diagnosis of breast cancer. In case of death, the Causes of Death Registry/Population Registry of Norway was consulted regarding the assumed cause of death. Follow-up time was assigned from the date of initial diagnosis to the beginning of February 2010 with date of death as censoring points. The Regional Committee for Research Ethics approved the study. The Regional Committee approved that written consent from the patients for their information to be stored in the hospital database and used for research was not needed because most of the material was more than ten years old and many of the patients are now dead.

\section{Tissue samples}

Representative formalin-fixed paraffin-embedded tissue blocks were obtained from the archives of the Department of Pathology at UNN. Clinical, biochemical and radiological observations up to the diagnosis of metastases were from the patients journals. Histological classification and grading of breast cancer was made in accordance to the World Health Organizations criteria and TMN-classification of malignant tumors [32,33]. Histological diagnoses were ductal carcinoma (34 cases) and lobular carcinoma (4 cases). Hormone receptor status was recorded at the time of the initial diagnose. Histological verification of metastases to axillary lymph nodes was performed at the Department of Pathology, UNN.. The material was collected from our approved biobank for paraffin embedded material and slides. All material was anonymously collected. The data were analyzed anonymously.

\section{Immunohistochemistry}

Antigen retrieval of COX-2 and IL-10 was performed with Protease I, in a final dilution of 1:100 for 4 and 16 minutes, respectively. Antigen retrieval of TGF- $\beta$ was performed in a microwave oven with Tris/EDTA buffer, $\mathrm{pH} 9.0$, for intervals of $2 \times 10 \mathrm{~min}$. Antigen retrieval of Ki67 was performed with steamer with Citrate buffer, $\mathrm{pH}$ 7, for $32 \mathrm{~min}$. The slides were then transferred to a Ventana Benchmark ${ }^{\circledR}$, XT automated slide stainer (Ventana Medical System, France). Tissue sections were incubated with primary polyclonal goat antibody against COX-2 (final dilution 1:100), monoclonal rabbit antibodies against TGF- $\beta$ (final dilution 1:50) and monoclonal mouse antibodies against IL-10 (final dilution 1:20). All antibodies were from Santa Cruz Biotechnology Inc, CA, USA. The mouse monoclonal antibody against Ki67 
was optimized for use in a Ventana automated slide stainer in combination with Ventana detection kit. As secondary antibodies, biotinylated goat-anti-mouse IgG and IgM, and goat-anti-rabbit IgG, both $200 \mu \mathrm{g} / \mathrm{ml}$, were used. For endogenous peroxidase blocking, the IVIEW $^{\mathrm{TM}}$ DAB Detection Kit (Ventana) was used. Finally, all slides were counterstained with haematoxylin to visualize the nuclei. For each antibody, including negative staining controls, all staining was performed in a single experiment. As negative staining controls, the primary antibodies were replaced with the primary antibody diluents. Appropriate positive and negative controls were included in each antibody run according to the manufacturer's recommendations. Single stromal cells within groups of epithelial cancer cells were defined as belonging to tumor cell areas. The tumor stromal areas were defined as stromal tissue surrounding groups of epithelial cancer cells in central parts of the tumor and were negative by IHC staining with antibodies directed against Cytokeratin (CK, Ventana). Stromal tissues in the periphery of the tumors were not investigated. For stromal cell characterisation, the slides were stained by Masson Trichrome (collagen fibres), Giemsa (granulocytes), Vimentin (fibroblasts), CD34 (vessels), CD20 (B-lymphocytes), CD3, CD4 and CD8 (T-lymphocytes), CD68 (macrophages), CD56 (NK-cells) and CD1a (dendritic cells) (all antibodies were fromVentana). Oestrogen receptors (ER) and progesterone receptors (PRs) were visualized using antibody 1D15 (Dako) and antibody NCL-PGR (Abbott Laboratories, Maidenhead, UK), according to a previously published protocol (34). The demonstration of oestrogen receptors (ER) were visualized using antibody 1D15 (Dako), and progesterone receptors (PRs), with antibody NCL-PGR (Abbott Laboratories, Maidenhead, UK), according to a previously published protocol [34]. The staining of ER and PRs was estimated using the "quick score" technique [34] as follows: slides were assessed for both the proportion of cells stained and staining intensity. Proportions were scored as 0 (no cells staining); 1) 1-25\%; 2) $26-50 \%$; 3) $50-75 \%$; or 4$)>75 \%$ stained cells. The intensity was scored as 0 , (no staining); 1 , (weak); 2, (moderate); or 3, (strong staining). The two scores were added to give a final score of 0-7. A final score $<3$ was regarded as negative.

\section{Digital video analysis}

Microscopic images for quantitative analysis were recorded with a Leitz Aristoplane microscope equipped with a Leica DFC 320 digital camera. The Leica QWin Image Analysing system (Leica Microsystems Digital Imaging Solutions Ltd, Cambridge, UK) was used for morphometric analysis. Leica DFC320 is based on a 3.3 megapixel sensor. The staining intensity of COX-2,
TGF- $\beta$, IL-10 and Ki67 in tumor cell areas and tumor stromal areas was quantified by measuring the colour value of red, green and blue colours (RGB), expressed in composite units. Density thresholds of RGB were set to quantify positive immunoreactivity of the red, green and blue colour components and these thresholds were fixed during the study. The number of pixels falling within each threshold ( 1 pixel $=0.172 \mu \mathrm{m})$ indicated the immunoreactivity reaction of each field and was recorded. The intensity of immunoreaction for each slide was expressed as the mean of RGB. Each slide was initially examined at $10 \times$ and $20 \times$ magnifications for an overall view. This practice allowed an area to be chosen as the most representative, with no tissue folding or overlapping, and minimal background staining. In each slide, ten different areas along a projected Z-line at $400 \times$ magnification comprising both tumor cell and stromal areas were systematically evaluated for the expression of COX-2, TGF- $\beta$, IL-10 and Ki67. Positive staining of COX-2 was assessed by the presence of marked diffuse brown cytoplasm in cancer cells (Figure $1)$. The staining intensity of COX-2 was scored as 0 (negative staining), 1 (weak), 2 (moderate), or 3 (strong staining) and the proportion of positive stained cells within each group were assessed. A combined staining index, SI, was calculated by multiplying the staining intensity $(0,1,2$, or 3$)$ by the percentage of positively stained cells within each group (Figure 1) [34]. The expression of TGF- $\beta$, IL-10 and Ki67 was recorded in single non-epithelial cells within groups of epithelial cancer cells (tumor cell areas) and in the surrounding tumor stromalareas in central parts of the tumor (tumor stromal areas).

\section{Statistical analysis}

Differences in staining intensity between primary tumors and metastases were analyzed By Wilcoxon signed rank test. Disease-specific survival was determined from the date of initial diagnosis to the time of breast cancer death. The risk of death from breast cancer in high (above median) and low (below median) staining intensity groups was compared by KaplanMeier survival analysis and log-rank test. COX-proportional hazards regression models were used to model the outcome death as a function of staining intensity. Age, histological grade (1-3), tumor size, oestrogenand progesterone receptor positivity (yes/no), were included in the models in separate analyses to adjust for possible confounding. Her2-neu was done in few patients and was therefore excluded from these analyses. Pearson's product moment correlation coefficient and Spearman's rank correlation were used in the reproducibility analysis. A two-sided $p$ value $<0.05$ was considered statistically significant. The SPSS 16.0 


\section{Tumor cell areas}

\section{Tumor stromal areas}

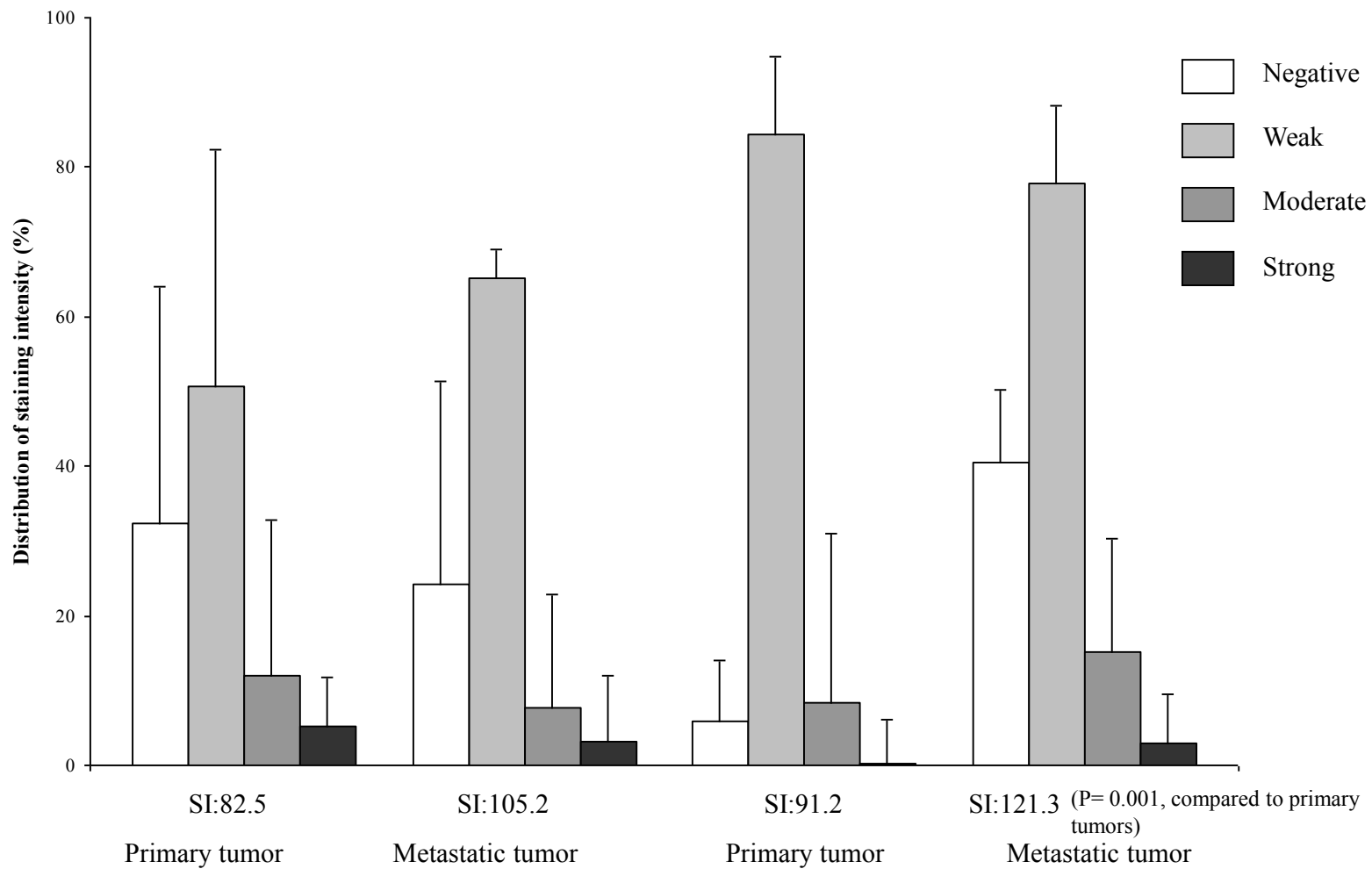

Abbreviation: $\mathrm{SI}=$ staining index: multiplications of staining intensity by percentage of positively stained cells within each group.

Figure 1 Expression of COX-2 in primary and metastatic tumors

software package was used in all analyses (SPSS Inc., Chicago, IL, USA). This study was approved by the Regional Committee for Research Ethics (REK, ref.200303108-3/IAY/400), and this study was supported by grants from the Northern Norway regional Health Authority (Helse Nord RHF).

\section{Results}

\section{Clinical features}

Patients' characteristics are listed in Table 1. Mean age was 61.3 years (range, 39-89). Fifteen patients died during the follow-up, and mean survival time was 45.6 months (range, 36-120 months). Histological grade 2 was the most common (53\%). Except for two, all patients had metastases to axillary lymph nodes at initial diagnose. Tumor size was > $10 \mathrm{~mm}$ in 36 (94.7\%) patients. Mean tumor size at histological grade 1, 2 and 3 was 2,4 , and $3 \mathrm{~mm}$, respectively. Oestrogen and progesterone hormone-receptor status were done in all tumors, 29 was oestrogen positive and 15 were progesterone positive.

\section{Expression of COX-2, TGF- $\beta$, IL-10 and Ki67}

Figures 1 and 2, and Table 2 illustrate the COX-2, TGF$\beta$, IL-10 and Ki67 staining pattern in tumor cell areas and tumor stromal areas of the primary specimens and their corresponding lymph node metastases. The expression of COX-2, TGF- $\beta$, and IL-10 were predominantly cytoplasmic. The overall expression of COX-2 was higher in the metastases compared to the primary tumors $(p<0.001)$ (Figure 1). In primary tumors as well as in the metastases, the expression of COX-2 was highest in the tumor stromal areas (both $p<0.001$ ). The staining indexes (SI) for COX-2 in tumor stromal areas were significantly higher in the metastases (121.3) compared to the primary tumors (91.2).

The expression of TGF- $\beta$ was highest in the tumor cell areas of both primary tumors and metastases (both $p<0.001$ ) (Table 2). IL-10 was expressed in cells with morphological features of macrophages and lymphocytes. The stromal expression was highest in the primary tumors $(p<0.001)$, whereas the tumor cell expression was highest in the metastases $(p<0.001)$ 
Table 1 Patients demographics and clinical characteristics $(N=38)$

\begin{tabular}{|c|c|c|c|}
\hline & Histological differention grade & & \\
\hline & 1 & 2 & 3 \\
\hline \multirow[t]{2}{*}{ Mean age (range), years } & $52.1(39-60)$ & $62.3(45-88)$ & $63.8(45-89)$ \\
\hline & $n=6$ & $n=20$ & $n=12$ \\
\hline \multicolumn{4}{|l|}{ Hormone receptor status } \\
\hline ER+ & 5 & 19 & 5 \\
\hline ER- & 1 & 1 & 8 \\
\hline PGR+ & 3 & 11 & 0 \\
\hline PGR- & 3 & 9 & 6 \\
\hline Her2-Neu+ & 1 & 0 & 6 \\
\hline Her2-Neu- & 2 & 4 & 2 \\
\hline \multicolumn{4}{|l|}{ Tumor size $(\mathrm{mm})$} \\
\hline $0-10$ & - & 1 & 1 \\
\hline $11-20$ & 2 & 9 & 3 \\
\hline $21-30$ & 1 & 6 & 4 \\
\hline $31-40$ & - & 3 & - \\
\hline$>40$ & 3 & 1 & 4 \\
\hline Mean & 2 & 4 & 3 \\
\hline
\end{tabular}

(Table 2). Ki67 expression (Table 2) was higher in stromal areas of the metastases $(p<0.001)$, whereas in primary tumors, the expression was highest in tumor cell areas $(p<0.001)$. Using the median as cut-off, the tumor and stromal expressions of the different markers Were categorized into a high versus low staining group. High expression of COX-2 was seen in tumor stromal areas of both primary tumors and the metastases (Figure 3 and Table 3, $p=0.020, p=0.003$, log rank test). High stromal staining intensity in the primary tumors was associated with a 3.9 (95\% CI 1.1-14.2) times higher risk of death compared to the low staining group $(p=0.036)$ (Table 3). After adjustment for age, histological grade, oestrogen and progesterone receptor positivity the risk estimate was weakened, but remained borderline significant. The corresponding unadjusted and fully adjusted risk estimates for the stromal areas in the metastases were 6.8 (1.5-30.4) and 8.3 (4.2-27.7) (Table 3). High stromal expression of TGF- $\beta$ in primary tumors wasassociated with increased mortality (HR 5.2, 95\% CI 1.124.0, $P=0.035)$. High IL-10 expression in tumor cell areas $(p=0.018)$ and stromal areas $(p=0.003)$ in the primary tumors predicted mortality, whereas high staining intensity in stroma of the metastases was borderline associated ( $p=0.057)$. Ki67 expression in tumor cell areas and stromal areas of the metastases was independently associated with breast cancer mortality.

\section{Discussion}

In both primary tumors and metastases, we observed higher expression of COX-2 in the Tumor stromal areas than in the tumor cell areas. For IL-10, a higher stromal expression was seen in the primary tumors only, whereas for Ki67 the stromal expression was highest in the metastases. High stromal expression of COX-2 and Ki67 in metastases, as well as high stromal expression of TGF- $\beta$ and IL-10 in primary tumors were independently associated to breast cancer mortality.

Mammary stromal tissue has a major role in the control and regulation of physiological processes in the breast. Likewise, during breast carcinoma development of the tumor stroma is believed to contribute in actively generating transformed lesions and tumors [35,36]. Evidence from genetic and clinical studies indicates that COX-2 up-regulation is one of the key steps in several preneoplastic lesions and cancers [37-41]. The role of COX-2 in the pre-invasive stages of breast tumorigenesis has been highlighted after recent publications, which linked the use of NSAIDs to decreased risk of breast cancer $[42,43]$. Our finding strengthens COX-2 as an important marker of breast cancer aggressiveness.

TGF- $\beta$ signalling pathways are involved in many biological processes during embryogenesis, tissue homeostasis and mammary epithelial growth $[44,45]$. During transformation of a normal cell into a cancer cell, various components of the TGF- $\beta$ signalling pathway may mutate, making the cell resistant to the effects of TGF- $\beta$ $[46,47]$. TGF- $\beta$ may suppress tumor growth in early stages, whereas at later stages TGF- $\beta$ may enhance tumor growth [48]. In spite of a higher TGF- $\beta$ expression in tumor cell areas, it was the stromal expression that was associated with breast cancer mortality in this 


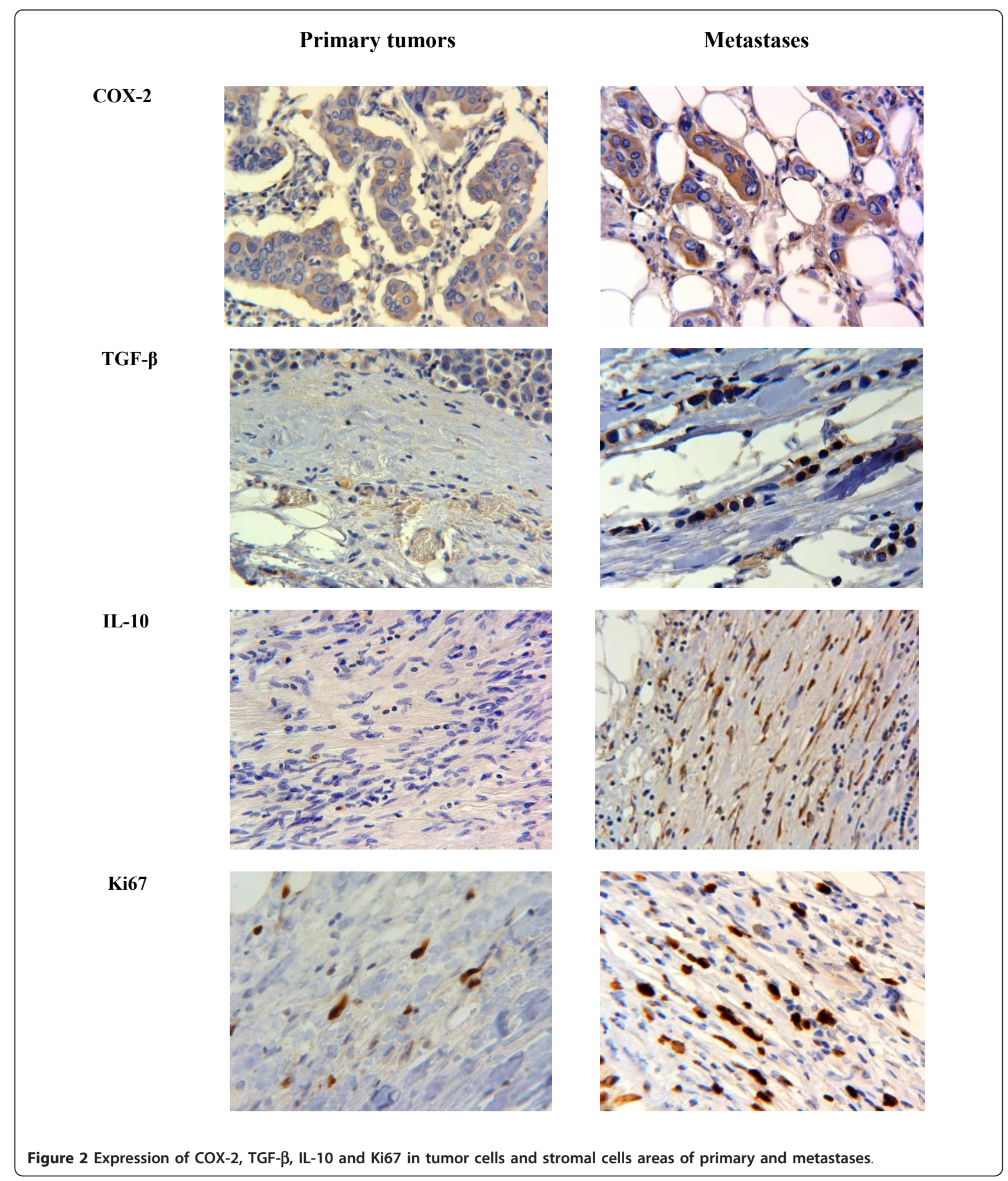

study. This may indicate that stromal expression of TGF- $\beta$ is particularly important in the early stage of tumor progression. Proliferative activity defined by Ki67 staining is associated with cancer progression and poor prognosis in a number of malignant tumors, including breast cancer [49]. Our study is in line with these reports, showing the highest expression of Ki67 in stroma of the metastases. 
Table 2 Distribution of TGF- $\beta$, IL-10 and Ki67 in tumor cell areas and tumor stromal areas and their corresponding metastases.

\begin{tabular}{lcccc}
\hline & & TGF- $\boldsymbol{\beta}$ & IL-10 & Ki67 \\
\hline TP & Median (IQR) & $760(580-862)$ & $395(204-715)$ & $676(545-764)$ \\
\hline SP & Median (IQR) & $250(119-377)$ & $610(291-791)$ & $326(238-454)$ \\
\hline TM & Median (IQR) & $781(693-904)$ & $656(433-887)$ & $419(165-723)$ \\
\hline SM & Median (IQR) & $220(92-273)$ & $426(255-273)$ & $751(539-855)$
\end{tabular}

The values are pr 1000 counted cells.

Abbreviation; IQR: interquartile range; TP: tumor cell areas of primary tumors; SP: tumor stromal areas of primary tumors; TM: tumor cell areas of metastatic tumors; SM: stromal cell areas of metastatic tumors.
The production and action of COX-2, TGF- $\beta$ and IL10 are interrelated. Some experimental studies have shown that Th2 lymphocytes release high levels of IL-10 and thereby induce COX-2 expression [22]. IL-10 and TGF- $\beta$ also cooperate to down-regulate immune responses. Studies on intestinal epithelial cells transgenic for IL-10 have shown that high TGF- $\beta$ production also controls the ability to respond to TGF- $\beta$ [21]. There are few studies comparing COX-2, TGF- $\beta$, and IL-10 expression in mammary tumor cell areas and tumor stromal areas. Except for TGF- $\beta$, the expression of COX-2, IL-10 and Ki67 in this study was higher in

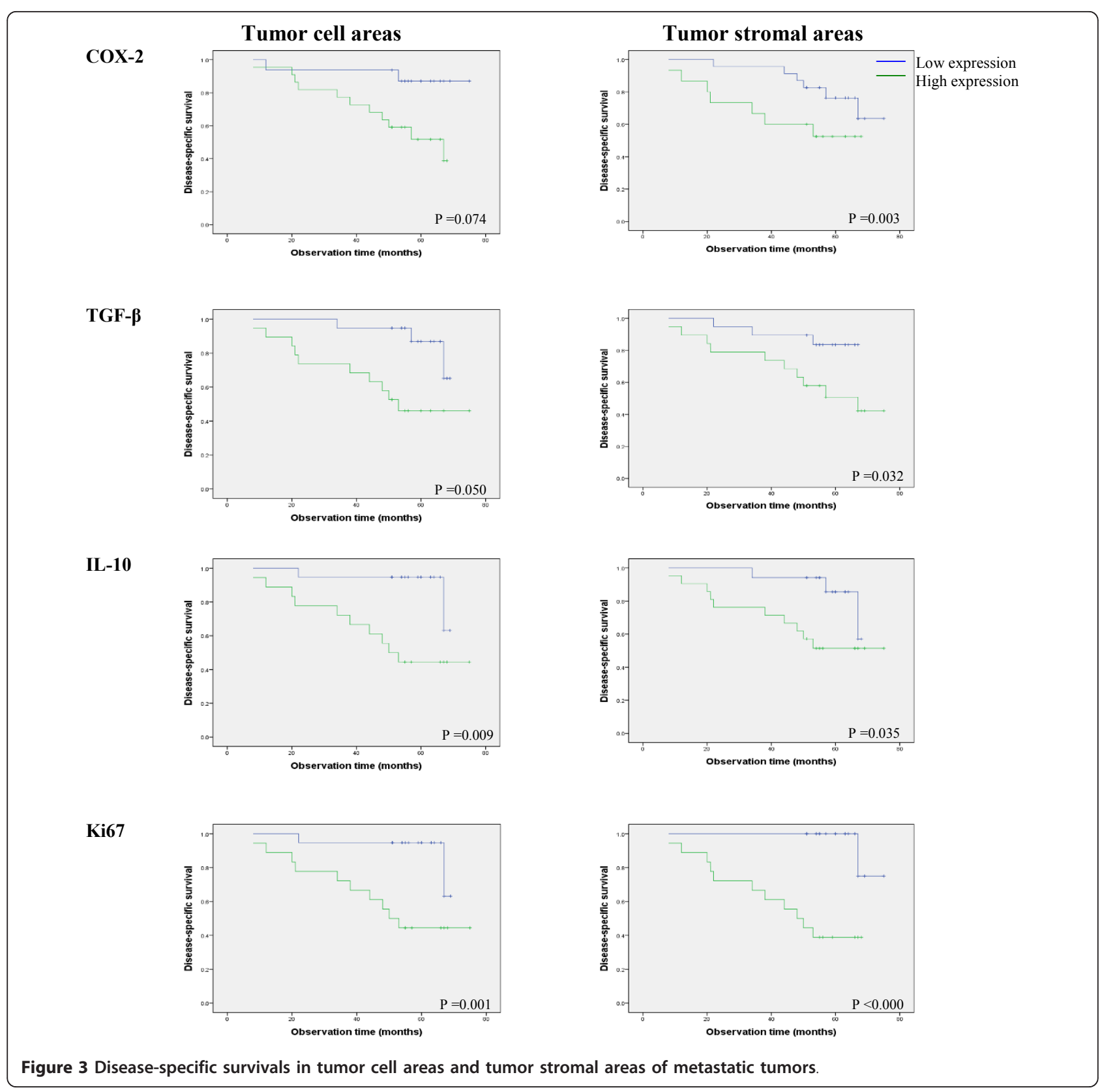


Table 3 Risk of death from breast cancer in high staining intensity groups compared to low staining intensity groups

\begin{tabular}{|c|c|c|c|c|}
\hline & & Log Rank test & Unadjusted HR (95\% Cl) & Multivariate adjusted $* \mathrm{HR}(95 \% \mathrm{Cl})$ \\
\hline \multirow[t]{4}{*}{ COX-2 } & $\mathrm{TP}$ & $P=0.322$ & $0.6(0.2-1.7), P=0.339$ & $0.6(0.2-2.2), P=0.485$ \\
\hline & SP & $P=0.020$ & $3.9(1.1-14.2), P=0.036$ & $3.5(0.8-14.7), P=0.059$ \\
\hline & TM & $P=0.074$ & $2.3(0.8-6.9), P=0.121$ & $1.5(0.4-6.0), P=0.592$ \\
\hline & SM & $P=0.003$ & $6.8(1.5-30.4), P=0.013$ & $8.3(4.2-27.7), P 0.024$ \\
\hline \multirow[t]{4}{*}{ TGF- $\beta$} & $\mathrm{TP}$ & $P=0.984$ & $1.0(0.3-2.8), P=0.989$ & $2.2(0.6-8.8), P=0.249$ \\
\hline & $\mathrm{SP}$ & $P=0.839$ & $1.1(0.4-3.3), P=0.842$ & $5.2(1.1-24.0), P=0.035$ \\
\hline & TM & $P=0.052$ & $0.4(0.1-4.1), P=0.069$ & $1.4(0.3-6.6), P=0.701$ \\
\hline & SM & $P=0.032$ & $3.0(1.0-9.2), P=0.046$ & $2.3(0.7-8.0), P=0.174$ \\
\hline \multirow[t]{4}{*}{ IL-10 } & $\mathrm{TP}$ & $P=0.130$ & $2.2(0.8-6.4), P=0.149$ & $5.2(1.3-20.6), P=0.018$ \\
\hline & $\mathrm{SP}$ & $P=0.384$ & $1.7(0.5-5.3), P=0.400$ & $1.1(1.0-1.8), P=0.003$ \\
\hline & TM & $P=0.009$ & $5.7(1.3-25.6), P=0.023$ & $4.7(0.8-25.5), P=0.076$ \\
\hline & SM & $P=0.035$ & $4.4(1.0-19.7), P=0.053$ & $4.0(0.8-20.7), P=0.057$ \\
\hline \multirow[t]{4}{*}{ Ki67 } & $\mathrm{TP}$ & $P=0.257$ & $1.8(0.6-5.3), P=0.275$ & $1.2(0.3-4.7), P=0.771$ \\
\hline & $\mathrm{SP}$ & $P=0.369$ & $1.7(0.5-6.1), P=0.387$ & $1.1(0.2-6.5), P=0.959$ \\
\hline & TM & $P=0.001$ & $7.7(1.7-35.2), P=0.008$ & $7.4(1.4-33.3), P=0.020$ \\
\hline & SM & $P<0.000$ & $3.6(1.0-12.9), P=0.031$ & $1.1(1.0-1.8), P=0.002$ \\
\hline
\end{tabular}

*Adjusted for age, histology (grade 1, 2 and 3, tumor size, oestrogen- and progesterone receptor positivity (yes/no).

Abbreviations: TP: tumor cell areas of primary tumors; SP: tumor stromal areas of primary tumors; TM: tumor cell areas of metastases; SM: tumor stromal areas of metastases

tumor stromal areas than in tumor cell areas. Our findings put emphasize on the surrounding stroma, supporting the hypothesis that the microenvironment surrounding tumor epithelium plays an important role in breast cancer progression. In future studies, both the tumor cell areas and the stromal areas should be investigated in primary breast cancer with or without metastases.

Most studies on human cancer tissues have evaluated immunohistochemical treated hotspot areas, where the staining intensity is highest. This is based on the assumption that one single section is representative for and reflects the histopathological pattern of the entire specimen. Moreover, the hotspot areas are evaluated without distinguishing between the tumor areas and the stromal areas. Instead of evaluating the protein expression in hotspot areas, we evaluated ten consecutively chosen fields along a projected Z-line in each tumor specimen. This approach was chosen to achieving a more representative picture of the tumor specimens and to put emphasizes on the role of stromal tissue in tumorigenesis.

In general, digital video analysis is regarded as being a more objective method with a higher sensitivity and reproducibility than light microscope and with better responsiveness to changes in cell counts [50,51]. However, there are technical pitfalls in this method, including background of the haematoxylin-eosin stained slides, the thickness of the slide, and tissue folding or overlapping, all which may cause bias in cell counting or assessment of protein expression. We excluded fields with tissue folding or overlapping from analysis. A shortcoming of this study is the small sample size. Our findings are on archived material, but should warrant a larger prospective analysis.

\section{Conclusions}

In this study, immunohistochemical stromal expression of COX-2, TGF- $\beta$, IL-10 and Ki67 was associated to breast cancer mortality. Our findings heighten stroma as an active participant in the carcinogenesis of breast cancer.

\section{Acknowledgements}

We want to thank the participating laboratory technicians at Department of Pathology, UNN, for their support and technical skills. Especially we want to thank Andreas Lindal, Mona Pedersen, Hege Marthe Hoe, Lena Myreng and Evy K. Johnsen for their very careful work. Financial support was given by The Northern Norway Regional Health Authority (Helse Nord RHF) and The Norwegian Cancer Society.

\section{Author details}

'Department of Clinical Pathology, University Hospital of Northern Norway, N-9038 Tromsø, Norway. ${ }^{2}$ Department of Medical Biology, University of Troms $\varnothing$, N-9037 Troms $\varnothing$, Norway. ${ }^{3}$ Department of Neurology and Neurophysiology, University Hospital of Northern Norway, N-9038 Tromsø, Norway. ${ }^{4}$ Department of Clinical Medicine, University of Tromsø, N-9037 Tromsø, Norway.

\section{Authors' contributions}

ER did the collection of tumor samples, and evaluated the immunohistochemical staining, the digital video analysis performed the statistical analysis and drafted the manuscript. RDU and ER performed the microscopic images for quantitative analysis. RDU performed the digital images. ER, LTB re-examined and histological graded the specimens. LTB 
participated in study design and extensively reviewed the manuscript. SHJ participated in data interpretation and reviewed the manuscript. All authors have read and approved the manuscript.

\section{Competing interests}

The authors declare that they have no competing interests.

Received: 23 August 2011 Accepted: 21 February 2012

Published: 21 February 2012

\section{References}

1. Bishop JM: Molecular themes in oncogenesis. Cell 1991, 64:235-248.

2. Bissel MJ, Radisky D: Putting tumors in context. Nat Rev Cancer 2001, 1(1):46-54

3. Kalluri R, Zeisberg M: Fibroblasts in cancer. Nature 2006, 6(5):392-401.

4. Bissel MJ, Barcellos-Hoff MH: The influence of extracellular matrix on gene expression: is struture the message? J Cell Sci 1987, 8:327-343.

5. Kim JB, Stein R, Hare MJ: Tumor-stromal interactions in breast cancer: the role of stroma in tumorigenesis. Tumor Biol 2005, 26(4):173-185.

6. Arent LM, Rudnick JA, Keller PJ, Kuperwasser C: Stroma in breast development and disease. Seminars in Cell \& Development Biol 2010, 21:11-18.

7. Yu H, Kortylewski M, Pardoll D: Crosstalk between cancer and immune cells: role of STAT3 in tumor microenvironment. Nature Rev Immunol 2007, 7(1):41-51

8. Courtois F, Gilmore RD: Mutations in the NK-KB signaling pathway: implications for human disease. Oncogene 2006, 25(51):6831-6843.

9. Rius J, Guma M, Schachtrup C, Akassoglou K, Zinkernagel AS, Niet V, Johnson RS, Haddad GG, Karin M: NF-kB links innate immunity to the hypoxic response through transcriptional regulation of HIF-1a. Nature 2008, 5(453):807-811.

10. Pikarsky E, Porat RM, Stein I, Abramovitch R, Amit S, Kasem S, GutkovichPyest E, Ureli-Shoval S, Galun E, Ben-Neriah Y: NK-кB functions as a tumour promoter in inflammation-associated cancer. Nature 2004 431(7001):461-466.

11. Xu K, Shu HK: EGFR activation results in enhanced cyclooxygenase-2 expression through p38 mitogen-activated protein kinase-dependent activation of $\mathrm{Sp} 1 / \mathrm{Sp} 3$ transcription factors in human gliomas. Cancer Res 2007, 67(13):6121-6129.

12. Bierie B, Moses HL: TGF- $\beta$ and cancer. Cytokine Growth Factor Rev 2006, 17(1-2):29-40

13. Flanders KC, Wakefield LM: Transforming growth factor- $\beta$ s and mammary gland involution; functional roles and implications for cancer progression. J Mammary Gland Biol Neoplasia 2009, 14(2):131-144.

14. Marceel M, Leroy A: Clinical, cellular, and molecular aspects of cancer invasion. Physiol Rev 2003, 83(2):337-376.

15. Roberts AB, Sporn MB, Assoian RK, Smith JM, Roche NS, Wakefield LM Heine UI, Liotta LA, Falanga V, Kehrl JH: Transforming growth factor type $\beta$; rapid induction of fibrosis and angiogenesis in vivo and stimulating of collagen formation in vitro. Proc Natl Acad Sci, USA 1986 83(12):4167-4171.

16. Steiner MS, Zhou ZZ, Tonb DC, Barrack ER: Expression of transforming growth factor- $\beta 1$ in prostate cancer. Endocrinol 1994, 35(5):2240-2247.

17. Oft $M$, Heider $\mathrm{KH}$, Beug $\mathrm{H}$ : TGF- $\beta$ signalling is necessary for carcinoma cell invasiveness and metastases. Curr Biol 1998, 8(23):1243-1252.

18. Pasche B, Kolachana P, Nafa K, Satagopan J, Chen YG, Lo RS, Brener D, Yang D, Kirstein L, Oddoux C, Ostrer $H$, Vineis $P$, Varesco L, Jhanwar $S$, Luzzato L, Massagué J, Offit K: TbetaR-1(6A) is a candidate tumor susceptibility allele. Cancer res 1999, 59(22):5678-5682.

19. Mocellin S, Wang E, Marincola FM: Cytokines and immunoresponse in the tumor microenvironment. J Immunother 2001, 24(5):392-407.

20. Mantovani A, Sozzani S, Locate M, Allavena P, Sica A: Macrophage polarization: tumor-associated macrophages as a paradigm for polarized M2 mononuclear phagocytes. Trends Immunol 2002, 23(11):549-555.

21. Howell WM, Rose-Zerilli MJ: Cytokine polymorphisms, cancer susceptibility, and prognosis. J Nutr 2007, 137(1 suppl):194S-1995.

22. Huang S, Ullrich SE, Bar-Eli M: Regulation of tumor growth and metastases by interleucin-10: the melanoma experience. J Interferon Cytokine Res 1999, 19(7):697-703.
23. Mocellin S, Marincola FM, Young HA: Interleukin-10 and the immune response against cancer: a counterpoint. J Leucocyte Biol 2005, 78(5):1043-1051

24. Llanes-Fernandez L, Alvarez-Goyanes Rl, Arango-Prado Mdel C, ArangoPrado Mdel C, Alcocer-Gonzales JM, Mojarrieta JC, Perez XE, Lopez MO, Odio SF, Camacho-Rodriguez R, Guerra-Yi ME, Madrid-Mariana V, Tamezguerra R, Rodriguez-Padilla C: Relationship between IL-10 and tumormarkers in breast cancer. The Breast 2006, 15(4):482-489.

25. Langsenlehner U, Krippl P, Renner W, Yazdani-Biuki B, Eder T, Köppel H, Waschner TC, Paulweber B, Samonigg H: Interleukin-10 promoter polymorphism is associated with decreased breast cancer risk. Breast Cancer Res and Treat 2005, 90(2):113-115.

26. De Azambuja E, Cardoso F, de Castro G Jr, Colozza M, Mano MS, Durbecq V, Sotiriou C, Larsimont D, Piccart-Gebhart MJ, Palesmans M: Ki-67 as prognostic marker in early breast cancer: a met-analysis of published studies involving 12555 patients. British J Cancer 2007, 96(10):1504-1513.

27. Barcellos-Hoff MH: It takes a tissue to make a tumor: epigenetics, cancer and the microenvironment. J Mammary Gland Biol Neoplasia 2001, 6(2):213-221

28. Maffini MV, Soto AM, Calabro JM, Ucci AA, Sonnenschein C: The stroma as a Crucial target in rat mammary gland carcinogenesis. J Cell Sci 2004, 117(pt8):1495-1502.

29. Wiseman BS, Werb Z: Stromal effects on mammary gland development and Breast cancer. Science 2002, 296(5570):1046-1049

30. Coussens LM, Werb Z: Inflammatory cells and cancer: think different! $J$ Exp Med 2001, 193(6):23-26

31. Schor S, Schor A: Phenotypic and genetic alterations in mammary stroma: implications for tumour progression. Breast Cancer Res 2001 3(6):373-379.

32. World Health Organizations; Tumors of the Breast and female Genital Organs. 2003, ISBN 9283224124.

33. TMN - classification of Malignant Tumors. , 6, UICC 2002, ISBN 0471 222887

34. Barnes DM, Harris WH, Smith P, Millis RR, Rubens RD: Immunohistochemical determination of oestrogen receptor: comparison of different methods of assessment of staining and correlation with clinical outcome of breast cancer patients. Br J Cancer 1996, 74(9):1445-1451.

35. Bhowrmic NA, Neilson EG, Moses HL: Stromal fibroblasts in cancer initiation and progression. Nature 2004, 432(7015):332-337.

36. Holliday DL, Brouilette KT, Markert A, Gordon LA, Jones JL: Novel multicellular organotypic models in normal and malignant breast: tools for dissecting the role of the microenvironment in breast cancer progression. Breast Cancer Res 2009, 11(1):R3.

37. Wu T: Cyclooxygenase- 2 and prostaglandin signalling in cholangiocarcinoma. Biochem and Biophys Acta 2005, 1755(2):135-150.

38. Lagarde SM, Kate FJW, Richel DJ, Offerhaus GJA, Lanschot JJB: Molecular Prognostic factors in adenocarcinoma of esophagus and gastroesophageal junction. Ann Surg Oncol 2006, 24(26):4347-4355.

39. Fournier DB, Gordon GB: COX-2 and colon cancer: potential targets for chemoprevention. J Cell Biochem Supp/ 2000, 34:97-102.

40. Gupta RA, Dubios RN: Colorectal cancer prevention and treatment by inhibition of cyclooxygenase-2. Nat Rev Cancer 2001, 1(1):11-21.

41. Singh-Ranger G, Salhab M, Mokbel K: The role of Cyclooxygenase 2 expression in breast cancer. Breast Ca Res Treat 2008, 109(2):189-198.

42. Surowiak P, Maternal V, Matkowski R, Szczuraszek K, Kornafel J, Wojnar A: Relationship between expression of cyclooxygenase 2 and MDR1/Pglycoprotein in invasive breast cancers and their prognostic significance. Breast Cancer Res 2005, 7(5):862-879.

43. Hu M, Peluffo G, Chen H, Gelman R, Schnitt S, Polyak K: The role of COX-2 in epithelial - stromal cell interactions and progression of ductal carcinoma in situ of the breast. Proc Natl Acad Sci 2009, 106(9):3372-3377, 3.

44. Beisner J, Buck MB, Fritz P, Dippon J, Schwab M, Brauch H, Zugmaier G, Pfizenmaier $\mathrm{K}$, Knabbe C: A novel functional polymorphism in the transforming growth Factor beta2 gene promoter and tumor progression in breast cancer. Cancer Res 2006, 66(15):7554-7561, 1

45. Kong FM, Anscher MS, Murase T, Abbot BD, Iglehart JD, Jirtle RL: Elevated plasma transforming growth factor- $\beta 1$ levels in breast cancer patients decrease after surgical removal of tumor. Ann Surgery 1995 222(22):155-162 
46. Levy L, Hill CS: Alteration in components of the TGF- $\beta$ superfamily signalling pathways in human cancer. Cytokine Growth Factor Rev 2006, 17(1-2):41-58

47. Baselga J, Rothenberg ML, Tabernero J, Seoane J, Daly T, Cleverly A, Berry B, Rhoades SK, Ray CA, Fill J, Farrington DL, Wallace LA, Yingling JM, Lahn M, Artega C, Carducci M: TGF- $\beta$ signaling-related markers in cancer patients with bone metastasis. Biomarkers 2008, 13(2):217-236

48. Derynck R, Akhurst RJ, Balmain A: TGF- $\beta$ signalling in tumor suppression and cancer progression. Nat Genet 2001, 29(2):117-129.

49. Potemski P, Pluciennik E, Bednarek AK, Kusinska R, Jesionek-Kupnica D, PaszWalczak G, Watala C, Kordek R: Ki-67 expression in operable breast cancer: A comparative study of immunostaining and real-time RT-PCR assay. Pathology Res and Practice 2006, 36(3):291-295.

50. De Boer WI, Hiemstra PS, Sont JK, De Heer E, Rabe KF, Van Krieken JH, Sterk PJ: Image analysis and quantification in lung tissue. Clin and Exp Allergy 2001, 31(3):504-508.

51. Sullivan P, Stephens D, Ansari T, Costello J, Jeffrey P: Variation in the measurements of basement membrane thickness and inflammatory cell number in bronchial biopsies. Eur Respir 1998, 12(4):811-815.

doi:10.1186/1756-0500-5-110

Cite this article as: Richardsen et al:: Immunohistochemical expression of epithelial and stromal immunomodulatory signalling molecules is a prognostic indicator in breast cancer. BMC Research Notes 2012 5:110.

\section{Submit your next manuscript to BioMed Central and take full advantage of:}

- Convenient online submission

- Thorough peer review

- No space constraints or color figure charges

- Immediate publication on acceptance

- Inclusion in PubMed, CAS, Scopus and Google Scholar

- Research which is freely available for redistribution

Submit your manuscript at www.biomedcentral.com/submit
C Biomed Central 